\title{
Digitalization of labor market parameters to improve the efficiency of the enterprise's personnel policy
}

\author{
Vitaliy Komlev ${ }^{1, *}$, Elena Barmina ${ }^{1}$, and Oksana Feoktistova ${ }^{2}$ \\ ${ }^{1}$ Vyatka State University, Moskovskaya str., 36, Kirov, 610000, Russia \\ ${ }^{2}$ Moscow State Technical University of Civil Aviation, 125009, Kronshtadsky, 22, Moscow, Russia
}

\begin{abstract}
The article analyzes the characteristics of the labor market on the Internet that affect the formation of personnel policy of the enterprise. The authors propose a developed software product to order the processing a large amount of information and determine the parameters and key indicators which determine the successful personnel policy of the enterprise. The software tools includes an analysis of the basic parameters of the labor market on the Internet: the ratio of supply and demand for major vacancies, average wages of supply and demand, the dynamics of supply and demand, taking into account the region (territorial specifics). The possibilities of programmatic monitoring of the labor market in order to promptly adjust the personnel policy of an organization to key personnel positions based on the dynamics of changes in the labor market environment make it possible to increase the effectiveness of personnel policy and its productivity. Comparative analysis of key parameters of the labor market in various cities of the Russian Federation and possible directions of personnel policy formation in the major vacancies in organizations allows optimal analysis of large amounts of information opened on the Internet (job banks, data of personnel and recruiting agencies, job banks and resume in social networks taking into account the region), allows you to quickly and correctly make management decisions in the field of personnel management. The article discusses the contact of the parameters of the labor market with the main directions of the personnel policy of the enterprise: the organization of personnel selection, adaptation, training, motivation and incentives, evaluation, etc., taking into account possible personnel risks.
\end{abstract}

\section{Introduction}

In the conditions of unstable development of the economy, connected, among other things, with the introduction of various kinds of sanctions, the significance of such an enterprise resource as personnel is significantly increased. Personnel is the main and decisive resource of any organization, the main factor of production, the first productive force of society. They create, set in motion and improve the means of production (means of

\footnotetext{
* Corresponding author: ganebnykh@mail.ru
} 
labor and objects of labor). The effectiveness of the activities of any organization largely depends on the qualifications of the staff, their training, and business skills. The quality of the organization's personnel directly depends on the effectiveness of the implementation of the personnel policy of the enterprise.

The solution of the personal policy target may consist of the choice of several alternative options (between elements of an open or closed personnel policy):

- to invest in the retention of employees in the organization or to expand the search and attraction of new employees;

- search the labor market for people who already have the required level, or invest in the training of their own employees;

- strive to improve team cohesion or develop healthy competition among employees (replacing the worst found in the labor market);

- the question of using paid sources to deploy experts while searching for the required specialist.

In the formation of personnel policy, the following factors should be taken into account:

1) production requirements, enterprise development strategy;

2) the financial capabilities of the enterprise, determined by it the permissible level of costs for personnel management;

3 ) the quantitative and qualitative characteristics of existing staff and the direction of their change in the future, etc.;

4) the requirements of labor legislation, the adopted culture of working with hired personnel, etc.;

5) the situation on the labor market (quantitative and qualitative characteristics of the labor supply by the professions of the enterprise, the conditions of the offer);

6) the demand for labor from competitors, the emerging level of wages [9].

If the first four factors are easily evaluated and unchanged for a relatively large time period (for example, development strategy, legal requirements, etc.), the labor market is in a state of constant dynamic changes (for example, seasonal fluctuations). Despite the fact that the labor market conjuncture is one of the key external factors influencing the formation of the personnel policy of an enterprise [1], nevertheless, in reality, the formation of personnel policy occurs on the basis of simpler factors in terms of analysis. For example, on the basis of the development strategy of an enterprise, the personnel management service is tasked to select employees of a certain skill level. If there is an excess of such employees in the labor market, then the task is easily accomplished, but if there is a shortage of such specialists, then after a long search, the organization must first apply to recruitment agencies, then make decisions about training and retraining employees, etc. Ultimately, the underestimation of the labor market as a key factor affecting the staffing of an enterprise leads to various kinds of personal risks: labor shortages in the enterprise and, as a result, additional costs for recruiting and training personnel, equipment downtime, forced admission of employees, qualified lower than required, etc.

Therefore, without active monitoring of the basic parameters of the labor market, it is virtually impossible to form an effective personnel policy. If the labor market situation is favorable, then the majority of personnel risks can be avoided; if not, then various personnel risks are inevitable, which lead to additional costs and the need for an unplanned adjustment of personnel policy.

The purpose of the study: the development of tools for monitoring and analyzing the main parameters of the labor market.

Objectives of the study:

1. The definition of the main parameters of the labor market, necessary for the formation of personnel policy of the enterprise. 
2. Identification of available sources of information for monitoring the basic parameters of the labor market.

3. Development of tools for monitoring the basic parameters of the labor market.

4. Development of a personnel policy formation system based on an analysis of the parameters of the labor market.

The key parameters of the labor market affecting the personnel policy of an enterprise are the ratio of demand and supply of labor and the average wage for a particular vacancy [15].

The most accessible source for analyzing the parameters of the labor market today are Internet resources related to the placement of vacancies and resumes [3].

All sites containing information about vacancies can be divided into several categories:

- Specialized employment sites, which are divided into:

- sites designed for the employer and the applicant. They contain questionnaire forms, job listings, employment advice: superjob.ru, hh.ru, www.job.ru, etc.;

- universal and specialized sites. Universal sites publish information for all applicants: www.resume.ru. Specialized sites are focused on a narrow segment of the market.

- Representative offices of newspapers: www.rabota.ru; www.job-today.ru. Most of the print publications devoted to the work have their own Internet presence: "Profession", "Vacancy" "Labor Exchange", etc.

- Representative offices of recruitment companies, on the site of which one can find a description of fresh vacancies, a mini-resume of specialists, tips on employment and personnel search, analytical reviews of the market.

- Sites of large companies. The "Jobs" section not only makes the company more open, thereby working on its positive image but also contributes to the effective search for specialists in key positions [6].

A sufficiently large number of Internet sources on the labor market, on the one hand, makes it possible to carry out an extensive and reliable analysis, on the other hand, websites with resumes and vacancy announcements contain a vast array of information. And daily monitoring of even a few of them, for example, with a simpler goal than the formation of personnel policy — finding the right employee — can take quite a long time. This was manifested in the great popularity of a number of computer programs, such as E-Staff, Resumagic, Resumax, which allow parsing of websites based on regular expressions, accumulating key information about applicants (full name, work experience, education, etc.) e), in one database, and carry out simple analytical operations. That is, they allow you to solve the problem with improving the efficiency of recruitment in the organization.

Analysis of the labor market on the Internet in order to formulate an enterprise's personnel policy is a more complex task. As discussed earlier, the minimum set of parameters for personnel policy development is the ratio of supply and demand for a particular vacancy and the average salary level. In analyzing the main parameters of the labor market on the Internet, the following problems arise:

1) different HTML code on various sites for which labor market parameters are analyzed, since the analysis of vacancies on only one site is not a valid source of information;

2 ) the difference in the classification system of vacancies and resumes at different sites. So, for example, on the website hh.ru, the "Automotive business" section includes vacancies of both the "mechanic" and the "purchasing manager" and "sales manager in companies related to road transport". At the same time, the site superjob.ru such vacancies are placed in different sections: "Transport", "Logistics of foreign trade activities" and "Sales", respectively.

Thus, the data obtained often cannot fully be reliable "starting points" for making management decisions. 


\section{Methods}

VSU has developed a software product "RLM", which allows for the parsing of open information sites with announcements of vacancies and resumes of applicants. With the help of this program, the research was conducted by analyzing the labor market on the Internet and analyzing documents on the development of personnel policy at the enterprises of Kirov.

\section{Results and discussion}

The RLM software proposed by the authors is designed to solve the problem of analyzing a large amount of data, structured according to various parameters and characteristics, which make it difficult to verify the required indicators in a particular network resource. To ensure the validity of the proposed system analysis of the labor market, using the software product "RLM", contains the following modules:

1. Module of recognition of significant parameters (job title, resume and proposed salary for this position) on the basis of regular expressions of open information on sites.

2. The module for the classification of vacancies and resumes on the same topic. For example, the following titles of vacancies and resumes can be assigned to the "Sales" class: "sales manager", "sales representative", "realtor", "insurance agent", "promotion manager", "customer service manager", "Sales Manager", "Sales Manager Specialist", "Sales Officer", "Sales Agent", "Active Sales Manager", "Regional Representative", Salesman ".

3. Analysis of the ratio of supply and demand in the labor market for the corresponding vacancy class and resume and calculation of average wages.

4. The monitoring system of the time trend of the ratio of supply and demand and the average wage.

Thus, when processing open source data containing verified labor market data for a specific region, one can rely on more reliable data when making management decisions in the field of HR management of a particular organization.

For example, according to the results of the analysis of the RLM program on the labor market in Moscow and Kirov based on the analysis of open information of sites with databases of vacancy announcements and resumes on 06.06.2018, 18.07.2018 and 18.08.2018, individual vacancy groups were as follows (Table 1 and Table 2):

Table 1. The ratio of supply and demand for individual vacancy groups in Moscow.

\begin{tabular}{|l|c|c|c|c|c|}
\hline № & Job Group & $\begin{array}{c}\text { Number of } \\
\text { Vacancies }\end{array}$ & $\begin{array}{c}\text { The Number of } \\
\text { Resume }\end{array}$ & $\begin{array}{c}\text { Demand/ } \\
\text { Offer }\end{array}$ & $\begin{array}{c}\text { Average salary } \\
\text { of an employer in } \\
\text { rubles }\end{array}$ \\
\hline 1 & Sales Manager & 143 & 53 & 2.7 & 63304 \\
\hline 2 & HR manager & 16 & 18 & 0.89 & 48928 \\
\hline 3 & accountant & 18 & 35 & 0.51 & 54800 \\
\hline 4 & economist & 6 & 15 & 0.4 & 55000 \\
\hline 5 & lawyer & 15 & 19 & 0.79 & 63180 \\
\hline 7 & IT specialist & 21 & 4 & 5.25 & 122666 \\
\hline 8 & marketing & 5 & 7 & 0.71 & 70000 \\
\hline 9 & logistics & 5 & 15 & 0.33 & 41500 \\
\hline 10 & administrator & 26 & 34 & 0.76 & 45293 \\
\hline 11 & design & 12 & 9 & 1.33 & 63708 \\
\hline 12 & engineer & 43 & 53 & 0.81 & 61517 \\
\hline 13 & supervisor & 40 & 184 & 0.22 & 91187 \\
\hline 14 & merchandiser & 6 & 2 & 3.0 & 23000 \\
\hline
\end{tabular}


Table 2. The ratio of supply and demand for individual groups of vacancies in Kirov.

\begin{tabular}{|c|c|c|c|c|c|}
\hline № & Job Group & $\begin{array}{c}\text { Number of } \\
\text { Vacancies }\end{array}$ & $\begin{array}{c}\text { Number } \\
\text { of Resume }\end{array}$ & $\begin{array}{c}\text { Average } \\
\text { Demand/ } \\
\text { Offer } \\
\text { salary of an } \\
\text { employer in } \\
\text { rubles }\end{array}$ \\
\hline 1 & Sales Manager & 106 & 69 & 1.54 & 32990 \\
\hline 2 & HR manager & 14 & 15 & 0.93 & 27700 \\
\hline 3 & accountant & 18 & 75 & 0.24 & 23560 \\
\hline 4 & economist & 24 & 16 & 1.5 & 21968 \\
\hline 5 & lawyer & 11 & 46 & 0.24 & 34460 \\
\hline 7 & IT specialist & 18 & 5 & 3.6 & 43466 \\
\hline 8 & marketing & 24 & 4 & 6.0 & 27578 \\
\hline 9 & logistics & 4 & 10 & 0.4 & 21666 \\
\hline 10 & administrator & 20 & 77 & 0.26 & 24700 \\
\hline 11 & design & 6 & 8 & 0.75 & 25000 \\
\hline 12 & engineer & 41 & 90 & 0.46 & 40661 \\
\hline 13 & supervisor & 55 & 231 & 0.24 & 41355 \\
\hline 14 & merchandiser & 5 & 3 & 1.67 & 21526 \\
\hline
\end{tabular}

In total, 12873 vacancy announcements and 12654 resumes on the Internet were analyzed.

For example, in both Moscow and Kirov, the number of sales manager vacancies significantly exceeded the number of resumes. Accordingly, in order to find a good specialist in the labor market, the organization must offer more attractive working conditions. And, conversely, the number of vacancies "accountant" is significantly less than the resumes submitted. In this case, the organization can tighten the requirements for candidates and, accordingly, for its employees, since finding a replacement for an employee is not difficult.

The "supply / demand" ratio in the specialty "economist" is different in Moscow and Kirov. If in Moscow, the number of resumes exceeds the number of vacancies, respectively, an organization with the lowest cost can find the necessary specialist, in Kirov, on the contrary: demand exceeds supply, therefore, to find a suitable specialist you need to create more favorable employment conditions for candidates and use paid sources attracting candidates.

Development of personnel policy of the enterprise as a result of the parsing of sites is carried out as follows:

In that case, if the demand in the labor market for this vacancy significantly exceeds the supply (D>S), then the vacancies in the labor market are much more than the resume of applicants. Personnel policy, in this case, has a tendency to closed type. To preserve the personnel potential, the organization is forced to take measures to retain employees and actively use internal sources of personnel attraction. There may be inter-organizational labor migration, when employees, already working in any organization, continue to actively monitor the labor market and submit announcements in order to find a job with higher wages or better working conditions. The company is forced to bear certain costs in order to attract candidates better than those of competitors in the labor market, to invest in their development and retention, to maintain the organization's personal potential at a level sufficient to solve the tasks facing the staff. 
If the demand in the labor market for this vacancy is significantly less than the supply $(\mathrm{D}<\mathrm{S})$, then the vacancy in the labor market is significantly less than the resume of applicants. In this case, the personnel policy tends to be open-ended: the organization has a choice among applicants - the requirements for its own staff are tightened, there may be a constant search for more qualified candidates on the labor market than their own employees and their periodic replacement.

The second significant indicator in the analysis of the labor market is the level of the average wage for a particular vacancy. One of the main functions of wages is the formation of the interest of the employee in productive work [6]. In fact, the level of wages is one of the key factors that keep specialists in this organization and makes the organization more or less attractive to applicants in the labor market.

An important criterion in this question is the ratio of the proposed wage for a particular vacancy to the average wage in the labor market. If the company's salary is higher than the average salary in the labor market, then the organization (other things being equal) can count on attracting higher-level specialists (more work experience, education, business skills, etc.) and, accordingly, tighten the requirements both for candidates and for their own employees. In this case, the level of staff turnover is also reduced. An employee who has decided to quit for some reason from this organization is more difficult to find a job with an appropriate salary level, since the level of competition for job candidates is still high.

The negative points are that non-optimal personnel costs, reduced profitability of production, additional forms of material incentives (bonuses, bonuses, etc.) become more significant for employees at a higher level than in other organizations. The HR Manager is faced with a large number of responses to post vacancy announcements. This increases the complexity of their closure due to the time spent studying the resume, interviewing and testing, approval of candidates.

If the company's salary is lower than the average salary level of this category of professionals in the labor market, the organization will be of interest to higher-level specialists if it could afford more attractive working conditions (career prospects, development opportunities, etc.). In the absence of these conditions, the majority of candidates will be with a minimum set of professional characteristics. Moreover, the organization has to take into account the turnover of specialists, who, having obtained relevant work experience (usually 2-3 years), will look for better-paying jobs. That is, to retain good specialists, the organization either has to create certain conditions, introduce additional motivation options, or accept the situation when it is a "starting company" for young employees without work experience and regularly monitor the labor market in search of new candidates. The latter option may have all the signs of open personnel policy. With this approach, one of the main advantages may be the fact that the organization will receive a regular flow of new ideas from young professionals. On the other hand, there is a significant risk of losing confidential information.

Examples of personnel policy development based on the analysis of sites on the Internet for the specialty Sales Manager and Accountant are presented in Table 1.

The ratio of supply and demand in the labor market of Kirov in the specialty "sales manager" is 1.4 , i.e. there is a shortage of labor. The ratio of supply and demand in the labor market in Kirov in the specialty "accountant" is 0.21 , that is, there is an excess of labor.

In this case, the company's personnel policy regarding these vacancies will be as follows (Table 3).

Table 3. Examples of the main directions of the personnel policy of the enterprise for the vacancies "sales manager" and "accountant" based on the analysis of the "supply / demand" ratio on the Internet. 


\begin{tabular}{|c|c|c|}
\hline $\begin{array}{l}\text { Directions of } \\
\text { personnel policy }\end{array}$ & Sales Manager & Accountant \\
\hline $\begin{array}{c}\text { Search and } \\
\text { personnel recruitment }\end{array}$ & $\begin{array}{l}\text { - connects the maximum number of } \\
\text { sources of attraction, including paid } \\
\text { (media, employment agencies, etc.); } \\
\text { - Actively working with educational } \\
\text { institutions; } \\
\text { - the role of internal sources of staff } \\
\text { involvement increases }\end{array}$ & $\begin{array}{c}\text { - minimizes costs, because paid } \\
\text { sources are not involved, because } \\
\text { there are many candidates; } \\
\text { - active monitoring of the labor } \\
\text { market is organized in order to find } \\
\text { the best candidate; } \\
\text { - the following problem arises: a } \\
\text { large number of candidates respond } \\
\text { to the announcement, which makes } \\
\text { the selection procedure more } \\
\text { laborious }\end{array}$ \\
\hline $\begin{array}{l}\text { Candidate selection } \\
\text { criteria }\end{array}$ & $\begin{array}{l}\text { the number of selection criteria is } \\
\text { reduced to the minimum necessary, } \\
\text { there remain basically those criteria that } \\
\text { can indicate the formation of } \\
\text { professional competencies }\end{array}$ & $\begin{array}{l}\text { The number of selection criteria is } \\
\text { maximized to increase the } \\
\text { possibility of choosing the most } \\
\text { optimal candidate along with } \\
\text { professional skills, social } \\
\text { competencies are also actively } \\
\text { evaluated. }\end{array}$ \\
\hline $\begin{array}{l}\text { Adaptation of new } \\
\text { employees }\end{array}$ & $\begin{array}{l}\text { the organization actively invests in the } \\
\text { development of the adaptation system, } \\
\text { so new employees will quickly master } \\
\text { the working conditions and do not quit } \\
\text { during the first year of work }\end{array}$ & $\begin{array}{l}\text { Adaptation system costs are } \\
\text { minimized, because the selection } \\
\text { system is based on the selection of } \\
\text { the most adaptive candidates; } \\
\text { increased labor market supply } \\
\text { allows you to quickly replace a } \\
\text { young employee who has problems } \\
\text { during the trial period }\end{array}$ \\
\hline $\begin{array}{l}\text { Organizational } \\
\text { culture }\end{array}$ & $\begin{array}{l}\text { aims to retain employees in the } \\
\text { organization; there are events for team } \\
\text { building, team building, etc. }\end{array}$ & $\begin{array}{l}\text { focused on healthy competition } \\
\text { between employees; the worst } \\
\text { employee is quickly replaced }\end{array}$ \\
\hline Motivation & $\begin{array}{l}\text { The main focus is on internal } \\
\text { motivation: on employee development, } \\
\text { career prospects, etc. }\end{array}$ & $\begin{array}{l}\text { external, more related to material } \\
\text { benefits, depending on the } \\
\text { contribution of the employee to the } \\
\text { work of the organization }\end{array}$ \\
\hline $\begin{array}{c}\text { Management } \\
\text { decisions on the } \\
\text { esults of certification }\end{array}$ & $\begin{array}{c}\text { in the case of a low score, an employee } \\
\text { is preferably directed to his } \\
\text { development }\end{array}$ & $\begin{array}{c}\text { in case of low marks, the employee } \\
\text { is sent for his dismissal or transfer } \\
\text { to a lower position }\end{array}$ \\
\hline
\end{tabular}




\section{Conclusions}

Therefore, the use of digitalization of the basic parameters of the labor market significantly expands the possibilities for the rapid development and adjustment of personnel policy in an enterprise, which in a timely manner allows avoiding possible damage from personnel risks.

Further work on the digitization of labor market parameters implies:

1. Development of a search for significant correlations between the main parameters, which will allow in the future to create a system for predicting changes in these parameters.

2. Development of a system for assessing the effectiveness of the work of educational institutions, based on an analysis of the periods of unemployment of graduates and their career growth, which can be tracked on the Internet.

3. Analysis of the causes of staff turnover in significant enterprises of the region.

\section{References}

1. T. Y. Bazarov, Psychology of personnel management. Theory and practice: a textbook for bachelors, 381 p. (Moscow: Yurayt, 2014)

2. E. A. Vasilyeva, Analysis of the unemployment rate as an element of regional employment studies, Human and industrial potential of the Russian economy in front of global and local challenges, pp. 69-75 (Samara, 2018)

3. T. V. Vasilyeva The impact of the Internet economy on the labor market in Russia, Questions of modern science and practice. University. IN AND, 2(51), p. 154-159 (Vernadsky, 2014)

4. V. R. Vesnin, Human Resource Management. Theory and Practice [Text]: textbook, 688 (Moscow, 2015)

5. A. S. Danilova, On the issue of human potential as a competitive advantage of an organization, In the world of scientific discoveries, 7.2(55), pp. 924-935 (2014)

6. A. Mottaeva, J. Ćetković, Advances in Intelligent Systems and Computing, 692, 1151-1159 (2018) doi: 10.1007/978-3-319-70987-1_123

7. I. Yu. Zaitseva, Employment and unemployment in Russia: analysis of major trends, Modern Research, 1(05), pp. 21-22 (Samara, 2018)

8. A. Ya. Kibanov, Personnel Management: Textbook, 3rd ed., (revised and expanded), 638 p. (Moscow, Infra-M, 2014)

9. L. N. Nikolova, D. G. Rodionov, M. A. Bahauovna, International Journal of Economics and Financial, 6(2), 246-252

10. O. A. Kozlova External factors determining the personnel policy of companies in the future, Actual problems of the humanities and natural sciences, $\mathbf{3 - 1}$, pp. 180-182 (2015)

11. V. A. Komlev, The system of basic indicators of the efficiency of the recruitment process in the enterprise, Bulletin of the North-Caucasian Federal University, 3(54), pp. 102-108 (2016)

12. G. N. Litvinenko, Human resource marketing as an effective tool for the interaction of internal and external labor markets, Scientific journal KubGAU, 129(5), pp. 1-12 (2017) 
13. O. L. Malysheva, Information personnel technologies in the mirror of the innovative challenges of the economy, Bulletin of Kazan Technological University. 20, pp. 323-325 (2013)

14. O. L. Malysheva, Innovative personnel technologies of personnel attraction in the conditions of modern realities of the labor market, Bulletin of Kazan Technological University, 1, pp. 331-335 (2014)

15. L. Kh. Nikiforova, Formation of personnel policy of the enterprise according to the results of monitoring the labor market, Science in the modern world: development priorities, 1, pp. 66-70 (2015)

16. A. Mottaeva, MATEC Web of Conferences, 170, 01053 (2018) doi: 10.1051/matecconf/201817001053

17. D. Radushinsky, A. Mottaeva, L. Andreeva, G. Dyakova, IOP Conf. Series: Earth and Environmental Science 90, 012137 (2017) doi :10.1088/1755$1315 / 90 / 1 / 012218$ 